\title{
Dialog dan Toleransi Beragama di Kota Ambon: Perspektif Bekas Pejuang Muslim Ambon
}

\author{
Religious Dialogue and Tolerance in the City of Ambon: A Perspective from \\ the Ambon Muslim Ex-Combatants
}

MUHAMMAD FARID 1

\begin{abstract}
Subsequent to piece declaration of Malino II in 2002, it was claimed that Maluku may sustain its peace in a much longer time. A numerous attempts on establishing harmonious dialogues between religions and the combatant leaders have also been initiated. Yet, the conflicts could never stop to occur. At the present time, supported with the mission of pluralism and multiculturalism, the efforts to generate interreligious dialogs continue to commence, despite the strong confrontation from the Muslim ex-combatants who believed that these efforts might originate new conflicts. This writing is made based on the result of a phenomenological study on the daily life of Muslim ex-combatants in Ambon city. The findings has shown that the ex-combatants had proposed a typical and unique design of dialog. In fact, the tolerance was a sort of "multiple tolerance", which has a closer connotation to the concept of tolerance (tasamuh) in Islam to the extent of displaying the act of receiving and forgiving without losing the sense of being cautious and conscious toward non-Muslim individuals. This embed mental state is set due to the past conflict which leaves a traumatic wound and excessive prejudices toward the non-Muslim community. However, in daily life, the Muslim ex-combatants still demonstrate an open and sincere conducts toward the non-Muslims-socialize and mingle with all. The Muslim excombatants have proven themselves to be an important role in taking part of the peace process in Maluku. The proposed dialogue and tolerance are designated for mutual tranquility and prosperity, with the basis of Islamic fundamental values.
\end{abstract}

Keywords: Ambon, Indonesia, interfaith dialogue, Maluku, religious tolerance

Maluku segera menerima isyarat rekonsiliasi pasca perang sejak tahun 1999. Para pengkaji mendapati sejumlah gerakan positif dari masyarakat sivil yang muncul secara signifikan pada tahun 2000, dan juga berbagai usaha yang digerakkan oleh LSM (Lembaga Swadaya Masyarakat) lokal, nasional, maupun internasional pada tahun-tahun berikutnya, dengan tujuan mendamaikan dua pihak bertelagah menuju suatu kesepakatan damai. Beberapa isyarat penting rekonsiliasi dilihat dari berbagai gerakan yang dikenal Baku Bae (istilah lokal yang bererti saling bermaaf-an", atau "bermaaf-maafan di antara sesama) yang melibatkan para pemimpin provinsi pada pertengahan tahun 2000 di Jakarta, para pemimpin sivil pada bulan Oktober di Bali, juga para tokoh adat, wakil-wakil kelompok pemuda, aktivis LSM

\footnotetext{
${ }^{1}$ Muhammad Farid, Ph.D., lecturer at Department of Theology and Dakwah, Institut Agama Islam Negeri Ambon, Jln. Dr. H. Tarmizi Taher, Kebun Cengkeh, Batu Merah Atas, AMBON 97582, Maluku, Indonesia, email: mfarid01@yahoo.com.
} 
(Lembaga Swadaya Masyarakat) dan para "pemimpin perang" pada bulan Desember 2000 di Jogyakarta (Goss 2000; Klinken 2010; Manuputty et al. 2014).

Dari berbagai gerakan dan dialog itu selanjutnya melahirkan Perjanjian Damai Malino II yang ditaja pemerintah dan sekaligus menjadi penengah antara wakil Muslim dan wakil Kristen pada bulan Februari 2002. Meski mengalami banyak penolakan, namun sebelas poin (Antaranya, mengembalikan supremasi hukum, melindungi negara kesatuan, membangun kebebasan bergerak, menghilangkan organisasi bersenjata, mengembalikan pengungsi ke rumah mereka, membangun kembali infrastruktur, menjaga netralitas pasukan keamanan, dan merekonstruksi sebuah universitas yang terintegrasi) menjadi pertanda berakhirnya konflik. Menyusul berakhirnya status Darurat Sivil, tanda-tanda kehidupan normal mulai terlihat, seperti; berkurangnya kehadiran tentera, kerelaan untuk menyerahkan senjata dari para pejuang, kembalinya para pengungsi ke desa mereka, beberapa infrastruktur yang diperbaiki, dan terjalin kembali interaksi antara kedua kelompok yang bermusuhan di berbagai ruang publik (Gos 2000: 28).

Pada tahun 2003, persis satu tahun setelah "janji damai" di Malino II, konflik komunal kembali pecah. Menyusul setelah itu, konflik di tahun 2011, tahun 2012, dan baru-baru ini di tahun 2015, meskipun yang terakhir terjadi di luar kota Ambon. Para pengkaji kembali menyusun logik apa yang harus digunakan untuk membaca situasi ini. van Klinken (2010) melihat problem konflik Maluku terletak pada upaya rekonsiliasi yang dibangun namun dalam kesunyian yang luar biasa. Sebelas point perjanjian Malino II yang menerangkan komitmen untuk mencari kebenaran tidak pernah terlaksana. Orang Ambon takut jika kebenaran terungkap akan 'membuka luka lama'. Braithwaite (2010) menyebut rekonsiliasi di Ambon disebut sebagai 'rekonsiliasi tanpa kebenaran' (Klinken 2010).

Berbeza dengan Klinken (2010), Barron et al. (2012: 39) dalam Seusai Perang Komunal melihat konflik susulan di Ambon disebabkan 3 faktor yang saling berjalin; iaitu motivasi elit, motivasi warga, dan lingkungan yang mendukung. Para elit bekas pejuang terbukti menjadikan konflik sebagai insentif ekonomi-politiknya. Sementara warga (non-elit pejuang) terus-menerus menjalin hubungan dengan para elit untuk memobilisasi kekerasan. Keadaan pun semakin diparah oleh keadaan sekitar di mana pasukan polis dan tentera sangat toleran terhadap kekerasan-kekerasan susulan.

Jika disederhanakan, terdapat tiga problem mendasar di Maluku yang menyebabkan kekerasan rentan terjadi; pertama, problem kebenaran konflik 1999 yang belum terungkap; kedua, kelemahan dialog, dan; ketiga, problem bekas pejuang yang mencari keuntungan dari kekerasan susulan. Tulisan ini akan mencermati tiga permasalahan ini dengan memberikan perspektif lain khusus untuk permasalahan yang terakhir. Tulisan ini menyandarkan pada hasil temuan penelitian lapangan yang dilakukan tahun 2014-2015 terhadap kehidupan sehari-hari bekas pejuang Muslim di kota Ambon. Dengan menggunakan pendekatan kualitatif-fenomenologis, penelitian mencoba menjawab dua hal: pertama bagaimanakah sikap dan pemahaman para bekas pejuang Muslim Ambon terhadap usaha dialog yang dibangun selama ini?; dan kedua bagaimanakah model-model toleransi yang dipraktikkan para bekas pejuang terhadap individu non-Muslim di kota Ambon?

\section{Literatur Dialog dan Toleransi Beragama}

Kung (1999) menyebutkan, "Tidak ada damai di dunia tanpa ada damai antar agama, dan tidak ada damai agama tanpa adanya dialog antar agama". Pastinya, tidak ada dialog antara agama tanpa adanya toleransi beragama. Maka, dialog dan toleransi adalah dua prasyarat mutlak bagi perdamaian agama itu sendiri.

Dialog secara harfiahnya bererti "bercakap-cakap", "bertukar pikiran dan gagasan" (Hardjana \& Agus 2007). Proses bercakap-cakap dan "bertukar-pikiran" umumnya dipahami terjadi antara dua orang atau lebih. Namun Bohm (t.th.: 2) dalam On Dialog, justeru 
menyebutkan, bahkan satu orang pun dapat berdialog dengan dirinya sendiri, selama memiliki rasa dan semangat dialog. Pada awalnya, gagasan dialog ditransformasikan dalam sejumlah karya kritik budaya seperti Mikhail Bakhtin dan Paulo Freire, dan teologi seperti Buber (1958) sebagai sebuah jawaban eksistensial dalam melawan keterasingan sosial pada masyarakat industri. Martin Buber menulis dalam bukunya I and Thou demikian:

The primary words are not isolated words, but combined words. The one primary words is the combination I-Thou...primary words do not signify things, but they intimate relations.

Kata 'Words' dalam pandangan Buber terlukis sebagai dunia hidup manusia, atau segala tindakan manusia. Jika diringkas, yang dimaksudkan primary words adalah kombinasi dari "Aku-Engkau" (I-Thou). "Engkau" di situ bererti sebuah hubungan kesedaran kesadaran dan komunikasi intens.

Dari Buber, diketahui bahawa dialog sesungguhnya tidak sekadar difahami sebagai hubungan saling-silang yang ringkas, atau sekadar hubungan fizik dua orang dalam sebuah interaksi. Dialog juga bukan semacam transaksi tawar-menawar tentang sesuatu untuk mencapai kesepakatan, atau bahkan sebuah konfrontasi antara pihak yang satu mempersoalkan pihak lain untuk memberi pertanggungjawaban. Sebaliknya, dialog sejatinya adalah sebuah "kesedaran" untuk saling mengerti dan memahami, menerima hidup damai, dan bekerja sama untuk suatu kesejateraan bersama. Di sini, dialog difahami sebagai hakikat kehidupan itu sendiri. Sebab, hakikat hidup manusia tidak sekadar makan, minum dan melakukan segala aktiviti fizik, melainkan, berdasarkan "kesedaran" akal budi dari Tuhannya, manusia hidup bersama-sama.

Dalam hidup bersama, sikap terbuka menjadi yang utama. Di sini, toleransi menjadi bahagian terpenting. Toleransi pada umumnya diertikan sebagai sikap "menerima" (acceptance) atau "kerelaan" (willingness) untuk menerima sikap-sikap dan keyakinankeyakinan yang berbeza meskipun tidak disetujui. Cohen (2004: 69) dalam bukunya What Tolerantion Is mendefenisikan toleransi beragama sebagai:

An act of toleration is an agent's intentional and principled refraining from interfering with an opposed other (or their behaviour, etc.) in situations of diversity, where the agent believes she has the power to interfere.

Bagi Cohen, prinsip "tidak mengganggu" menjadi hal utama dalam toleransi. Sebagaimana juga diafirmasi oleh Powel dan Clarke dalam Religion, Tolerance and Intolerance: Views from Across the Disciplines, namun keduanya memberikan pendasaran prinsip tersebut pada "kesengajaan", dan bukan sikap acuh-tak acuh. Maksudnya, jika individu tidak "mempertimbangkan" atau "tidak sengaja" untuk menahan diri dari mengganggu, maka tindakan tersebut tidak dapat disebut sebagai toleran. Bersikap "tidakmengganggu" (non-interference) harus berpegang pada landasan, meskipun tidak selalu bersifat moral, agar dapat disebut sebagai tolerance (Powel \& Clarke, t.th: 4).

Dalam literatur Islam, istilah "toleransi" terungkap secara kaya dalam beberapa sinonim kata bahasa Arab yang berbeza, iaitu; sabr, tahammul, tasamuh, dan modara. Kokew (2014), dalam Tasāmuh, Modārā, Tolerance: On questions of Translation, menunjukkan bahwa istilah "toleransi" dalam Islam berbeda dan sangat khas dibandingkan dengan toleransi menurut pemahaman "sekuler". Kata sabr misalnya, selain digunakan dalam konteks "ketabahan terhadap kekafiran (al-Quran, al-Anfal: 66), namun sabr juga mengandungi makna "waspada" atau berjaga-jaga terhadap sesuatu dalam ketakwaan kepada Allah (alQuran, Ali 'Imran: 200). Sementara tasamuh, tidak semata-mata toleransi dalam makna umum, melainkan terkandung arti "memberi" dan "menerima". Seorang muslim yang disebut 
mustamihin bermakna seorang yang; pemaaf, penerima, menawarkan, pemurah (layaknya tuan rumah kepada tamu), namun juga tidak sepenuhnya membuka diri dan menerima semua hal sehingga menekan dirinya sendiri, atau bahkan sampai berlawanan dengan prinsip-prinsip beragamanya (Abdul Rauf 1984: 100).

\section{Dialog dan Problematikanya dalam Masyarakat Ambon}

Sejak berlakunya konflik pada tahun 1999, usaha mengadakan dialog antara pemeluk agama telah dilakukan hasil usaha warga sivil, pemerintahan Pusat, pemerintah Daerah Maluku dan juga LSM. Terdapat dua pendekatan dialog semasa konflik; pertama pendekatan formalseremonial, dan kedua pendekatan kultural. Pendekatan formal-seremonial dilakukan dengan menghadirkan sejumlah tokoh dari masing-masing kelompok yang bertikai untuk menandatangani kesepakatan bersama, sekaligus melakukan deklarasi damai atau menahan diri dari konflik. Adapun pendekatan kultural, yaitu dialog dengan cara-cara adat khas Maluku seperti; panas pela, yaitu upacara adat antara dua desa yang memiliki ikatan persaudaraan untuk kembali mempererat persaudaraan mereka dengan cara makan patita atau makan bersama. Namun kedua pendekatan ini tidak berhasil mengurangi ledakan konflik yang terjadi di kota Ambon.

Pada pasca damai Malino II tahun 2002, dialog perdamaian yang diupayakan LSM maupun NGO semakin meningkat dan terasa lebih konkrit. Iaitu dengan mengadakan dialogdialog internal dengan publik, dan juga menjembatani dialog publik secara terbatas dan informal. Dialog-dialog itu bertujuan untuk kesedaran masyarakat terhadap dampak konflik, integrasi sosial, mendorong terjadinya interaksi antara para pengungsi berbeza agama; dan membangun ikatan jaringan distribusi keperluan dasar pengungsi. Namun tidak sedikit yang meragui kesan program-program tersebut kerana seringkali hanya sampai pada peringkat seminar dan bengkel sahaja. Dialog berhenti hanya di atas kertas kerja, draft-draft, lalu menjadi arsip, tanpa ada hasil nyata. Masalah ini menjadi salah satu alasan mengapa konflik susulan terus terjadi di kota Ambon.

Di masa kini, dialog agama kembali digerakkan oleh sejumlah tokoh LSM/NGO dengan dokongan penuh pemerintah provinsi Maluku. Antara kumpulan yang popular adalah komuniti LAIM atau Lembaga Antar Iman yang terus menerus mempromosikan dialog dengan dilandasi semangat pemahaman multikulturalisme dan pluralisme. Mereka mendasarkan pada pandangan bahwa sumber konflik dan kekerasan di Maluku disebabkan kurangnya kesadaran masyarakat untuk menerima realiti multikultural dan plural yang ada di Maluku. Warga Maluku dinilai masih sangat lemah untuk hidup bersama dalam nilai-nilai multikulturalisme dan pluralisme. Di sisi lain, kuatnya fahaman ekslusivisme yang berasaskan agama dan primordialisme berasaskan suku (negeri/desa) juga ikut mendorong konflik terbuka. Maka, seluruh kerja-kerja dialog antara pemeluk agama perlu berorientasi pada penanaman nilai multikulturalisme dan pluralisme pada masyarakat Maluku.

Beberapa tokoh perdamaian lintas agama Maluku, yang didokong pemerintah provinsi Maluku kemudian menggerakkan berbagai program berasaskan nilai-nilai multikulturalisme dan pluralisme yang telah mulai dikembangkan saat ini, antara lain; revitalisasi bentuk-bentuk kearifan lokal (local wisdom), pendidikan youth camp, pertukaran pemuda/mahasiswa lintas agama dan etnik serta living values education. Beberapa program yang bersentuhan langsung dengan pendidikan formal di sekolah, seperti; Kurikulum Pendidikan Multikultural bagi Guru, Magang Mahasiswa Islam dan Kristen, dan Live In para guru lintas Agama. Program seperti ini diyakini dapat mengatasai stereotyping atau pemberian label kepada kelompok lain, baik positif atau negatif yang terjadi di Maluku sejak lama, sekaligus menjadi salah satu instrumen transformasi peradaban yang efektif dalam membangun perdamaian sejati di Maluku (Wakano 2015:10). 


\section{Dialog Cara Pejuang}

Bekas pejuang Muslim memiliki cara yang khas dalam memandang dialog antara agama di Maluku. Dengan bekal pertempuran di masa lalu, dan berbagai usaha "janji damai" yang berulang kali diingkari oleh "musuhnya" dahulu, bekas pejuang Muslim menilai dialog seharusnya tidak sekadar berbentuk transaksi tawar-menawar tentang sesuatu untuk mencapai janji kesepakatan. Seperti misalnya "janji Malino" di Sulawesi tahun 2002, yang mereka tolak dengan tegas. Bekas pejuang Muslim menolak "Damai Malino", tapi bukan perdamaian itu sendiri. Sebab, damai bagi mereka, hendaklah bersifat jujur dan terbuka tentang apa yang terjadi di masa konflik. Perlu ada yang mengakui tentang peristiwa sadis yang dialami mereka. Jika kejujuran dan keterbukaan telah dilakukan, barulah orang dapat saling memberi dan menerima, dan bersepakat untuk hidup bersama. Janji damai Malino II bagi bekas pejuang berlawanan dari itu semua. Maka mereka menolaknya, pertamanya kerana apatis dengan aneka janji, bahkan skeptik terhadap ikatan perjanjian adat yang dulu dipandang suci. Kedua, kerana tidak adanya kejujuran sikap dari para elit tentang persoalan yang mendera mereka. Ketidakjujuran elit ini justru menjauhkan dialog dari tujuan utama, iaitu perdamaian.

Para bekas pejuang juga menyikapi berbagai usaha damai hari ini yang dianggapnya tidak tepat sasaran. Usaha damai pemerintah dinilai masih bersifat kepalsuan. Sementara yang diupayakan sejumlah LSM dan NGO masih belum menyentuh persoalan sebenar masyarakat. Paradigma pluralisme dan multikulturalisme yang dijadikan cara pandang program-program perdamaian sangat problematik, bahkan berbahaya bagi keyakinan agama. Seperti program live in bagi suri rumahtangga, atau bagi para mahasiswa. Mereka menilai program-program itu tidak memperhatikan batasan-batasan khusus yang dimiliki seorang muslim, seperti waktu-waktu beribadah, persoalan kesucian dari najis dan lain-lain. Sementara bagi para mahasiswa baru yang mengikuti program "magang" di sejumlah gereja ditakuti akan mengusik keyakinan aqidahnya sehingga goyah dan menjadi murtad.

Bekas pejuang Muslim bukan anti dialog, apalagi anti sosial. Praktik dialog yang dicontohkan bekas pejuang Muslim adalah dengan menjalin hubungan bersama individu non-muslim tanpa harus mengorbankan keyakinan agamanya. Beberapa kes didapati mereka ada yang bersahabat dengan individu non-muslim, yang sebelumnya dianggap musuhnya. Tema dialog dan perbincangan di antara mereka umumnya sekitar bidang pekerjaan dan persahabtan. Tidak banyak menyentuh persoalan keagamaan. Beberapa kes menunjukkan, bekas pejuang juga menghadiri perayaan sambutan Hari Krismas secara bersama, demi menjaga hubungan persahabatan dan persaudaraan, namun dalam batasan-batasan sikap; seperti ketika mengucap Selamat Hari Krismas cukup dengan "selamat", dan tidak mengikuti acara yang bersifat ritual seperti doa bersama. Hal ini dilakukan kerana menyedari bahawa urusan keyakinan agama tidak dapat dicampur-baurkan.

Beberapa gagasan pokok dari model dialog agama bekas pejuang; Pertama, Dialog yang didasari pada keimanan kepada Allah. Keimanan kepada Allah dan keyakinan akan kebenaran Islam adalah pengakuan mutlak dan tidak dapat ditawar bagi seorang bekas pejuang Muslim. Namun kebenaran mutlak agama Islam tidak serta merta membuatnya menolak keberadaan agama orang lain. Kedua, Dialog yang didasari pada ketaatan kepada perintah dan larangan Allah. Kepatuhan kepada perintah Allah menjadi dasar dialog antara agama bagi bekas pejuang Muslim. Kepatuhan kepada perintah Allah berwujud pada upaya menjalankan perintah Allah yang baik (amr ma'ruf) dan menjauhi larangan Allah (nahi munkar). Amr ma'ruf salah satunya adalah dengan menjalin hubungan dialog bersama individu berlainan agama, khususnya Kristian. Ketiga, Dialog yang tumbuh dari pengalamanpengalaman, refleksi, dan berbagai kesulitan hidup manusia. Mereka bersikap relatif terbuka terhadap dialog dalam perkara kemanusiaan. Meliputi semua hubungan antara individu 
agama yang positif dan konstruktif, yang diarahkan untuk saling memahami dan saling memperkaya antara satu sama lain.

\section{Toleransi Berganda}

Dialog dan persahabatan para pejuang dapat terjalin harmonis sejauh dirinya tidak menjadi objek atau diintervensi oleh sahabatnya itu. Individu Kristian bagi bekas pejuang Muslim selalu difahami dalam hubungan konflik Kehadiran orang-lain selalu dianggap sebagai ancaman terhadap dirinya. Orang lain tidak menghendaki kehadirannya. Hal ini terjadi akibat trauma konflik masa lalu yang masih sukar untuk dilupakan. Konflik tahun 1999 yang mendera hidup nya berawal dari keterusikan iman; di mana tulisan-tulisan bernada kebencian terhadap warga Muslim dan etnik pendatang terpampang jelas di jalanan, dirasakan begitu menyakitkan. Maka bagi mereka, hidupnya hari ini dapat dijalani dengan baik selama dirinya tidak diganggu. Hal ini bukan bererti hidupnya penuh curiga terhadap non-Muslim, melainkan hanya merasakan kecemasan yang tidak dapat diketepikan.

Hidup dalam kecemasan membuat para pejuang membangun sikap toleran yang khas terhadap non-Muslim di kota Ambon. Dapat disebut sebagai "toleransi berganda". Toleransi model ini memiliki dua aspek; pertama aspek kognitif-negatif, dan kedua aspek afektif-positif. Aspek pertama bertumpu pada sebuah keyakinan berlebihan (over generalized beliefs) terhadap kelompok-luar, di mana individu non-Muslim sebagai kumpulan yang belum dapat dipercayai dan memiliki keyakinan yang salah. Sementara aspek kedua bertumpu pada tindakan kesehariannya yang tetap membuka diri kepada non-Muslim dan peduli sosial. Ertinya, mereka tetap memiliki pandangan stereotaip dan prejudis terhadap non-Muslim namun terjadi hanya pada tahap pemikiran, gagasan, dan tidak sampai berdampak pada tindakan keseharian yang merendahkan (derogated) apalagi yang tidak menyenangkan terhadap individu Kristian secara langsung (direct non-interference).

Jika dicermati, model toleransi bekas pejuang Muslim lebih mirip kepada konsep tasammuh dalam Islam daripada toleransi dari sudut pandangan Barat. Mereka mencuba membuka diri, menerima perbezaan, bersahabat dengan "musuhnya" dahulu, namun tetap menjaga batas, berhati-hati, dan penuh waspada terhadap segala kemungkinan yang terjadi. Kecemasan akan terjadinya konflik susulan meliputi seluruh hidupnya. Namun kemiripan sikap mereka dengan model tasammuh bukan sekadar kerana mereka seorang Muslim, namun juga disebabkan pengalaman hidupnya di masa lalu yang penuh gejolak bersama nonMuslim yang tidak mungkin dilupakannya, sehingga memberi bekas pada tindakan dan pergaulannya hari ini terhadap kelompok non-Muslim.

Sebagai kesimpulan, sikap para bekas pejuang Muslim yang mempersoalkan pengungkapan kebenaran konflik tahun 1999 sama dengan apa yang menjadi kerisauan para pengkaji seperti Braithwaite (2012) atau Klinken (2007) yang menyebutnya dengan istilah non-truth reconciliation. Dengan keadaan ini, Maluku sesungguhnya sedang menyimpan bom waktu yang dapat meletus pada bila-bila masa. Sementara itu, masalah kerja-kerja dialog yang dibangun selama ini yang berlandaskan pada fahaman yang bertentangan dengan keyakinan dan jati diri orang Maluku, khususnya bagi bekas pejuang Muslim, juga menambahkan kerumitan persoalan yang ada.

Namun demikian, dialog dan toleransi beragama yang dipraktikkan para ekskombatan Muslim dapat menjadi harapan baru bagi masa depan damai Maluku, sekaligus menepis pandangan yang terlalu simplistis oleh beberapa ahli perihal eks-kombatan Maluku yang diklaim sebagai pribadi yang hanya mencari keuntungan materi. Sebaliknya, meski hidup dengan memori masa lalu yang sulit dihapuskan, mereka terus berupaya membangun kembali sendi-sendi kehidupan harmoni bersama non-muslim, antara lain melakukan dialog, dan menjalin persahabatan. Sesuatu yang bahkan tidak pernah mereka bayangkan sebelumnya akan dapat "bersahabat dengan musuhnya" dahulu. 
Model komunikasi dan dialog terjadi secara intens, meskipun dalam batasan-batasan yang tidak sampai mengorbankan keyakinan agamanya. "Toleransi Berganda" yang dipraktikkan lebih menyerupai konsep tasammuh dalam Islam, yaitu dengan menampilkan sikap menerima dan sabar pada satu sisi, namun juga waspada pada sisi lain. Bekas pejuang Muslim masih mempunyai suatu keyakinan berlebihan (over generalized beliefs) terhadap kelompok non-Muslim, namun tetap bersikap terbuka dan peduli terhadap orang lain atau non-Muslim dalam kesehariannya. Hal ini sekaligus bukti, bekas pejuang Muslim mampu menjadi bahagian penting dari proses perdamaian di Maluku. Melalui model dialog dan toleransi yang khas, namun tetap berlandaskan pada nilai-nilai ajaran Islam yang kukuh.

\section{References}

Al-Quran. 2015. Terjemahan Kementrian Agama Republik Indonesia

Abdul Rauf. 1984. A Muslim Reflections on Democratic Capitalis. Washington: American Enterprise Institute for Public Policy Research.

Abdul Rauf. 2011. Aku dan Liyan. Malang: Widya Sasana Publication

Barron, P. et.al. 2012. Seusai Perang Komunal. Yogjakarta: Pusat Studi Keamanan dan Perdamaian Universitas Gadjah Mada Yogyakarta

Bohm, D. t.th. On Dialogue. 1996. London: Routledge.

Braithwaite, J. \& Barithwaite, V. 2012. Anomie and Violence. Canberra: The Australian National University.

Cohen, A. J. 2004. What Toleration Is? Ethics. 115: 68-95.

Farid, Muhammad. 2005. Konflik dan Integrasi Sosial Pada Masyarakat Majemuk Ambon. Tesis Universitas Brawijaya Malang.

Goss, J. 2000. Understanding the Maluku Wars: Overview of Sources of Communal Conflict of Communal Conflict and Prospects for Peace, Department. of Geography University of Hawaii, Honolulu, HI 96822. Cakalele. Vol.11: 200.

Hardjana \& Agus, M. 2007. Komunikas Intrapersonal dan Interpersonal. Yogyakarta: Kanisius. Klinken, G.V. 2010. Dialog dan Refleksi Bersama 10 tahun konflik Maluku, Ambon 19 January

Klinken, G.V. 2007. Communal Violence Democratization in Indonesia: Small Town Wars. British Library Cataloguing in Publication Data. hh.88-106.

Kokew, Stephan. 2014. Tasāmuh̆, Modara, Tolerence - On questions of Translation. https://www.academia.edu/9492076/_Tasamuh_Modara_Tolerance_-_On_Questions _of_Translation.

Kung, H. 1999. Projekt Weltethos. Munchen: Pieper Verlag GmBH.

Manuputty, J. et.al, 2014. Carita Orang Basudara: Kisah-Kisah Perdamaian dari Maluku. Jakarta: Lembaga Antar Iman \& PUSAD Paramadina.

Powell, R. \& Clarke, S. t.th. Religion, Tolerance and Intolerance: Views from Across the Disciplines. Oxford: University of Oxford.

Wakano, Abidin. 2015. Pendidikan Multikultural Sebagai Media Deradikalisasi Agama di Maluku. Artikel pada Seminar Antara Bangsa UKM-IAIN Ambon. 